\title{
Protective features of monoclonal antibodies to Escherichia coli during experimental infection of mice with homologous and heterologous serotypes of E. coli
}

\author{
GIAMMARCO RAPONI, M. CRISTINA GHEZZI, MARIA T. LUN, GIULIO BIGOTTI*, \\ $†$ PIER G. NATALI and CARLO MANCINI
}

Institute of Microbiology, University of Rome 'La Sapienza' Ple Aldo Moro 5, 00185 Rome, *Department of Pathology, Catholic University of Rome 'S. Cuore', Lg. A. Gemelli, 100167 Rome and †Immunology Laboratory, 'Regina Elena' Cancer Institute, Via delle messi d'oro, Rome, Italy

\begin{abstract}
Murine monoclonal antibodies (MAbs) MTIF and ARM 1-4, recognising proteins on the surface of untreated Escherichia coli $06: \mathrm{K}^{-}$, protected $100 \%$ of mice challenged intraperitoneally with $2 \times L D 50$ of the same strain. MAb MTIF protected $70 \%$ of animals challenged with $2 \times$ LD50 of E. coli O111:B4, whereas ARM 1-4 gave complete protection. Lower survival was observed in mice given either $M A b$ and challenged with E. coli $0128: \mathrm{K}^{-}$, with values ranging from 30 to $42 \%$. However, the protection afforded against $\mathrm{E}$. coli $\mathrm{O} 111: \mathrm{B} 4$ and $\mathrm{E}$. coli $\mathrm{O} 128: \mathrm{K}^{-}$was significantly improved when the mice were pre-treated with a mixture of the two MAbs. Control mice, pre-treated with unrelated ascitic fluid and challenged with any of the E. coli serotypes, showed $100 \%$ mortality and organ histological lesions resembling those of the early stages of septic shock. The mice had high levels of circulating endotoxin and tumour necrosis factor- $\boldsymbol{\alpha}$ (TNF- $\boldsymbol{\alpha}$ ) at $90 \mathrm{~min}$ after challenge. In contrast, mice treated with MAbs and surviving the infection displayed moderate histological lesions, enhanced bacterial clearance and lower serum levels of TNF- $\boldsymbol{\alpha}$, despite circulating endotoxin levels that were higher than in the control group. Protection by the MAbs was probably due to the prevention of the bacterial spread to organs and of the cascade of events leading to septic shock. This occurred in spite of the presence of high levels of circulating endotoxin.
\end{abstract}

\section{Introduction}

Escherichia coli is one of the most common aetiological agents of hospital-acquired infection, causing about one-third of gram-negative bacteraemias $[1,2]$. Treatment of these clinical events remains difficult despite the use of potent antibiotics, and many strains are becoming resistant to antibiotic therapy [3]. Therefore, interest in the possibility of immunotherapy for such infections has emerged [4-6]. However, the complexity and the high degree of antigenic variability of the outer structures of gram-negative bacteria are major problems in finding common target epitopes. In an attempt to identify protective antigens shared by different serotypes $[7,8]$, monoclonal antibodies

Received 18 Feb. 1999; revised version accepted 16 Aug. 1999.

Corresponding author: Dr G. Raponi.
(MAbs), directed against epitopes on lipopolysaccharide (LPS), in particular against the core region of lipid $A$, have been reported to be effective in preventing fatal infections with gram-negative bacilli [9-13]. However, despite the attractive simplicity of this approach, it is still controversial and data regarding the existence of such cross-reactive antibodies and the nature of the target epitopes are conflicting $[14,15]$. A different approach was based on the observation that antibodies to outer-membrane proteins (OMPs) were found to be protective in experimentally-induced infections [16-21].

In the search for bacterial epitopes with a potentially wider cross-protection, an earlier study demonstrated that mice immunised with $\mathrm{E}$. coli $06: \mathrm{K}$ - pre-exposed to a subminimal inhibitory concentration of a $\beta$-lactam antibiotic showed enhanced protection against homologous and heterologous bacterial lethal challenges compared with mice immunised with untreated bacteria 
[22]. The enhanced protection was transferred to normal mice by sera from mice immunised with antibiotic-treated bacteria, thus suggesting a key role for antibodies. In further studies, several MAbs were produced from the spleens of $B A L B / c$ mice immunised with $\mathrm{E}$. coli $06: \mathrm{K}^{-}$pre-exposed to antibiotic $[19,20]$. The MAbs identified protein epitopes on the surface of the untreated $E$. coli, were able to activate complement and gave protection against lethal challenge with homologous and, to a certain degree, against heterologous $E$. coli serotypes $[19,20]$. The present study was done to gain further insights into the mechanism of protection conferred by these MAbs.

\section{M aterials and methods}

\section{Bacteria}

E. coli 06: $\mathrm{K}^{-}$(ATCC 25922; Difco Laboratories Detroit, MI, USA), E. coli 0111:B4 (kind gift of Professor J. Verhoef Eijkman, Winkler Laboratory for Medical Microbiology, University Hospital of U trecht, The Netherlands) and E. coli 0128: $\mathrm{K}^{-}$(kindly provided by Professor A. Caprioli, Istituto Superiore di Sanità, Rome, Italy) were used.

\section{Animals}

Female BALB / c mice (N ossan, Correzzana, Italy) 6-8 weeks old and with an average weight of $25 \mathrm{~g}$ were used. The mice were housed in groups of five and provided with food and water ad libitum. The Institute's Ethical Committee approved all animal experiments. Care was taken to avoid any pain to the animals.

\section{MAbs}

Murine MAbs MTIF and ARM 1-4 were produced and purified by protein $G$ chromatography as reported previously $[19,20]$. To elicit the MAbs, the mice had been immunised with $\mathrm{E}$. coli $06: \mathrm{K}$ - grown overnight in the presence of $0.5 \times$ MIC of aztreonam (BristolMyers Squibb, Rome, Italy) and then killed with formalin [22]. Both MAbs were of the IgG1 isotype. MTIF reacted with a polypeptide of $12 \mathrm{kDa}$ [19] and ARM 1-4 with polypeptides of 30 and $40 \mathrm{kDa}$ [20] in the untreated $\mathrm{E}$. coli $06: \mathrm{K}^{-}$.

\section{Protection studies}

Passive protection experiments were performed in triplicate in groups of 10 mice. Animals were inoculated intraperitoneally (i.p.) with $1 \mathrm{ml}$ containing MTIF (5 $\mu \mathrm{g} /$ mouse), ARM 1-4 (5 $\mu \mathrm{g} /$ mouse) or a mixture of MTIF (2.5 $\mu \mathrm{g} /$ mouse $)$ and ARM 1-4 (2.5 $\mu \mathrm{g} /$ mouse). After $90 \mathrm{~min}, 2 \times \mathrm{LD} 50$ of live $\mathrm{E}$. coli $06: \mathrm{K}^{-}, \mathrm{E}$. coli $0111: \mathrm{B} 4$ or $\mathrm{E}$. coli $0128: \mathrm{K}^{-}$(the LD50 for these strains was $3 \times 10^{7}, 1 \times 10^{8}$ and $1 \times 10^{8} \mathrm{cfu} /$ mouse, respectively) were injected i.p. As a control group for each challenge strain, five female
$B A L B / C$ mice received $1 \mathrm{ml}$ of ascitic fluid induced by murine myeloma SP1 cells, instead of the test MAb. The absence of toxicity of the MAbs at the doses used was determined in groups of five mice. Mice were checked daily for 10 days and deaths were recorded. Results were expressed as the mean percentage survival and SD of three independent experiments.

\section{Bacterial clearance}

At 1,3 and $5 \mathrm{~h}$ after challenge with $2 \times \mathrm{LD} 50$ of $\mathrm{E}$. coli 06: $\mathrm{K}^{-}$, five mice from each group (controls and MAb-treated mice) were anaesthetised with diethyl ether and killed by cervical dislocation. After aseptic removal, livers and lungs were weighed, each was placed in $50 \mathrm{ml}$ of sterile saline, and homogenised under a vented hood. Ten-fold serial dilutions of the homogenates were made and $10 \mu \mathrm{l}$ of each dilution were plated on MacConkey agar. The plates were incubated for $18 \mathrm{~h}$ at $37^{\circ} \mathrm{C}$ and then the colonies were counted. Results are expressed as cfu/mg of homogenised tissue and are the means and SD of three independent bacterial counts of each organ sample.

\section{Serum collection}

At 90 min after challenge, five mice from each group were anaesthetised and bled from the retro-orbital plexus. Sterile precautions were taken throughout the procedures. The sera harvested from each group were pooled and stored in $0.1-\mathrm{ml}$ volumes at $-70^{\circ} \mathrm{C}$ until analysed.

\section{Endotoxin determination}

The endotoxin contamination of the MAb preparations, the unrelated ascitic fluid and the media used during the experiments, as well as the endotoxin levels in sera drawn after challenge of the mice and diluted 1 in 10, was determined in triplicate by the chromogenic Limulus amoebocyte lysate (LAL) test $(\mathrm{QCL}-1000$, Bio-W hittaker, Walkersville, MD, USA) according to the manufacturer's instructions.

\section{TNF - $\alpha$ determination}

TNF- $\alpha$ levels were measured in sera by the cytolysis produced in actinomycin D-sensitised fibroblast cell line L-929 [23]. Results were expressed in $\mathrm{U} / \mathrm{ml}$. One unit of TNF- $\alpha$ bioactivity was expressed as the titre that produced $50 \%$ cytolysis, based upon two-fold dilutions of serum samples. This endpoint corresponded with $35 \mathrm{SD} 8 \mathrm{pg} / \mathrm{ml}$ of a recombinant human TNF- $\alpha$ standard (Endogen, Boston, MA, USA). All positive samples were incubated with rabbit anti-mouse TNF- $\alpha$ polyclonal antiserum (IP-400; Genzyme, Boston, MA, USA) and tested for inhibition of TNF- $\alpha$ bioactivity in L-929 cells, to confirm true positivity. 


\section{Histology}

Histological examination of two mice from each group and randomly selected from those that died after bacterial challenge, along with two mice that survived the infection was done within $24 \mathrm{~h}$ of bacterial injection. The latter were anaesthetised with diethyl ether and killed by cervical dislocation $24 \mathrm{~h}$ after challenge. Furthermore, two mice taken randomly from the survivors were killed after 10 days. The brains, lungs, livers and spleens were removed and perfused with formaldehyde $10 \%$ in phosphate buffer (pH 7.8), dehydrated and processed in paraffin. Sections were cut at $5 \mu \mathrm{m}$ and stained with haematoxylin and eosin $(H \& E)$ or Giemsa.

\section{Statistical analysis}

Data obtained after bacterial challenge were expressed as the mean percentage survival and SD for three independent experiments each with groups of 10 mice. Survival of different groups was compared by the $\chi^{2}$ test. Multiple linear regression and non-parametric analysis were used to determine the correlation between serum TNF- $\alpha$ and mortality in each set of mice; $p$ values $<0.05$ were considered to be significant.

\section{Results}

\section{Protection studies}

All the control mice pre-treated with ascitic fluid and challenged with $2 \times L D 50$ of the different $E$. coli strains died within $24 \mathrm{~h}$ of challenge. The known protective capacity of M TIF and ARM 1-4 was verified by passive transfer experiments. Both MAbs gave $100 \%$ protection against lethal challenge with $\mathrm{E}$. coli $06: \mathrm{K}^{-}$(Fig. 1). When the animals were inoculated with $2 \times$ LD 50 of E. coli 0111:B4, the survival ranged from $70 \%$ to $100 \%$, and ARM 1-4 showed a protective activity significantly greater $(p<0.05)$ than that of MT1F. Survival of animals challenged with $E$. coli 0128: $\mathrm{K}^{-}$ranged from $30 \%$ to $42 \%$, and did not differ significantly between the two MAbs.

When the mice were treated with the two MAbs together and challenged with $\mathrm{E}$. coli $06: \mathrm{K}^{-}$, their survival approached $100 \%$ and no significant differences were observed between the groups treated with the single $M A b$ and with the mixture (Fig. 1). However, when the animals given the $M A b$ mixture were challenged with $E$. coli $0111: B 4$, their mean survival approached $90 \%$, and the protective capacity compared with MT1F was significantly $(p<0.05)$ improved. Furthermore, in mice inoculated with the mixture and subsequently challenged with $E$. coli 0128: $\mathrm{K}^{-}$, mean survival was $63 \%$ and protection was significantly $(p<0.001)$ higher than with either MT1F or ARM 1-4 alone.

\section{Bacterial clearance}

To verify whether the MAbs were able to prevent bacterial spread to the organs after i.p. injection, colony counts in lung and liver homogenates were obtained from controls and from mice protected with the MAbs

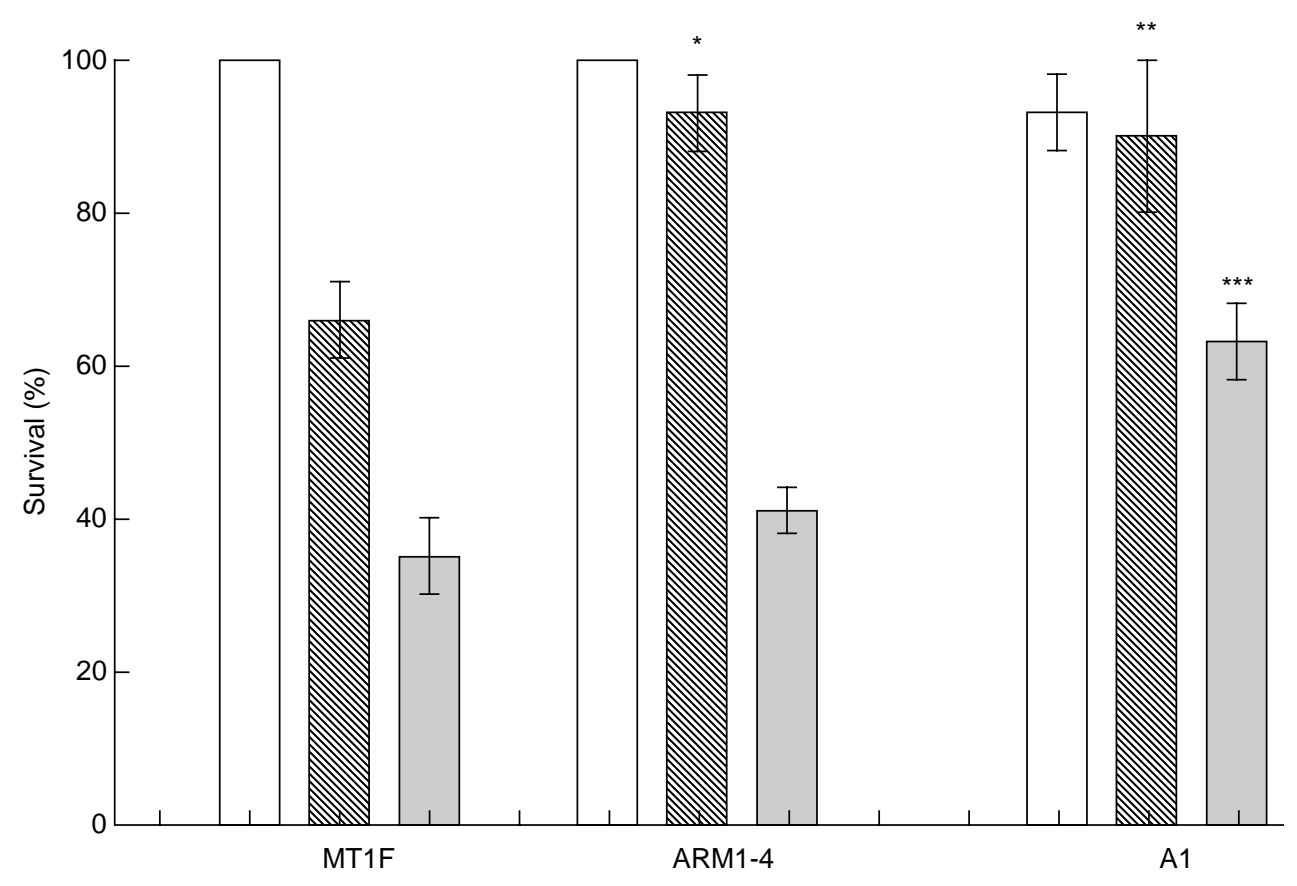

Fig. 1. Survival of mice pre-treated with MT1F, ARM 1-4 or with a mixture of MT1F and ARM 1-4 (A 1) and challenged with $2 \times L D 50$ of $E$. coli $06: K^{-}(\square)$, E. coli $0111: B 4(\mathbb{N})$ or $E$. coli $0128: K^{-}(\square)$. Data are expressed as the mean percentage survival and SD from three independent experiments. ${ }^{*} p<0.05$ ARM $1-4$ versus MT1F; **p $<0.05$ A 1 versus MT1F; ***p $<0.001 \mathrm{~A} 1$ versus both MT1F and ARM1-4. 
alone or in combination. Live $\mathrm{E}$. coli $06: \mathrm{K}^{-}$was recovered mostly in the liver while fewer bacteria grew from lung homogenates of either control or MAbtreated mice. In control animals, the bacterial counts in both lung and liver samples increased with time (Fig. 2). In contrast, animals that had received MAbs either alone or in combination showed, in all instances, bacterial counts significantly lower than those of control mice ( $p<0.001$, Student's $t$ test). The numbers of bacteria recovered from organ homogenates of MAb-treated mice changed little with time, indicating that the MAbs controlled bacterial spread to the organs after i.p. challenge.

\section{Endotoxin measurements}

The endotoxin contamination of the MAb preparations, ascitic fluid and the media used throughout the study was $<32 \mathrm{pg} / \mathrm{ml}$. Control and MAb-treated mice had serum endotoxin levels of 0.2 SD 0.05 and 0.24 SD $0.03 \mathrm{ng} / \mathrm{ml}$, respectively, before bacterial challenge. At $90 \mathrm{~min}$ after challenge with $\mathrm{E}$. coli $06: \mathrm{K}^{-}$, control

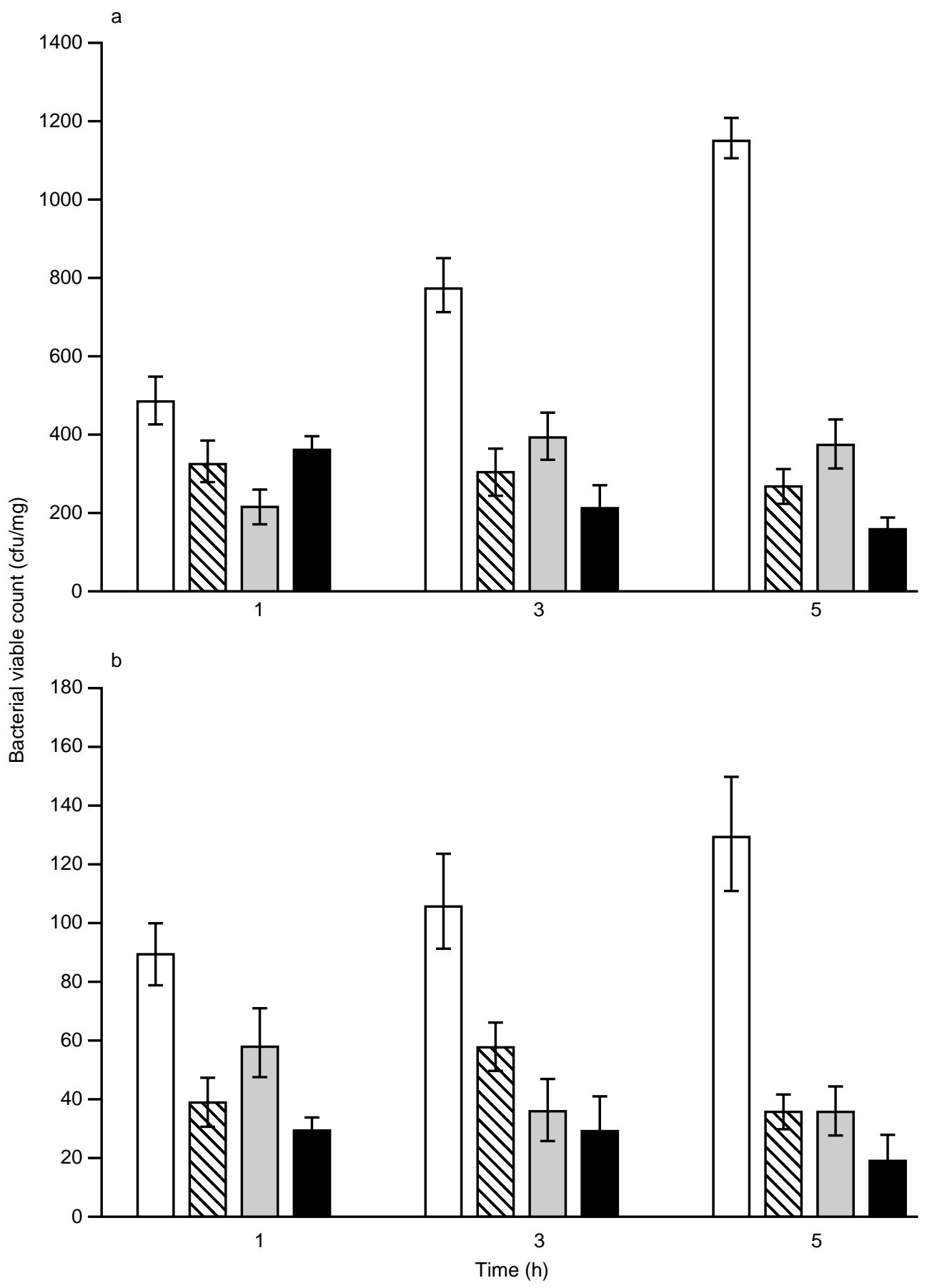

Fig. 2. Bacterial counts in (a) liver and (b) lung homogenates at 1,3 and $5 \mathrm{~h}$ after challenge with $2 \times L D 50$ of E.coli

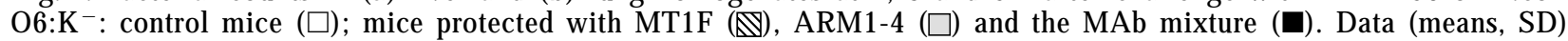
are expressed as cfu/mg of homogenised tissue. 
mice had values of $1.7 \mathrm{SD} 0.5 \mathrm{ng} / \mathrm{ml}$ whereas in mice pre-treated with MT1F, ARM 1-4 and with the MAb mixture, endotoxin levels were significantly enhanced (5.2 SD $0.3,4.8$ SD 0.6 and 5.6 SD $0.8 \mathrm{ng} / \mathrm{ml}$, respectively; $p<0.001 \mathrm{MAb}$-treated versus control mice). No significant differences in the serum endotoxin content were observed between each set of MAb-treated mice.

\section{Serum TNF - $\alpha$}

To find out the correlation, if any, between survival and systemic levels of TNF- $\alpha$, serum levels of the cytokine were measured $90 \mathrm{~min}$ after challenge with $\mathrm{E}$. coli $06: \mathrm{K}^{-}$. In control and MAb-treated mice, the levels of TNF- $\alpha$ ranged from $1.3 \mathrm{SD} 1.2 \mathrm{U} / \mathrm{ml}$ to $6.4 \mathrm{SD}$ $1.2 \mathrm{U} / \mathrm{ml}$ before bacterial challenge. After challenge, high levels of the cytokine were observed in control mice (158 SD $36 \mathrm{U} / \mathrm{ml}$ ), whereas in mice treated with either MAb or with the mixture, TNF- $\alpha$ levels were significantly lower (29.3 SD $7.2 \mathrm{U} / \mathrm{ml}$ for MT1F, 18.8 SD $2.8 \mathrm{U} / \mathrm{ml}$ for ARM 1-4 and $23.4 \mathrm{SD} 6.4 \mathrm{U} / \mathrm{ml}$ for the MAb mixture respectively; $p<0.001$, Student's $t$ test, MA b-treated versus control mice). Serum levels of TNF- $\alpha$ correlated significantly with mortality $(r=$ 0.95, B ravais Person test), with high levels of cytokine associated with a high mortality rate.

\section{Histology}

Organs from control mice that died within $24 \mathrm{~h}$ of challenge displayed features of systemic damage. The lungs showed diffuse atelectasis with marked thickening of the alveolar septa and leucocyte infiltration. The alveolar configuration was quite irregular with an alternation of emphysematous alveoli and alveoli compressed and obliterated (Fig. 3). The liver presented perilobular congestion with fatty and hydropic degeneration, as well as diffuse activation of the reticulo-endothelial system to confluent hepatocellular necrosis (Fig. 4). The spleen was generally fibrous and congested with conspicuous areas of haemorrhage and emperipolesis of white pulp (not shown). In the brains of the control mice, collapsed neurones with pycnotic nuclei and strongly stained eosinophilic cytoplasm were detected. Such neurones were diffusely identified in the cortical layers of the brain and sometimes in the Purkinje cells of the cerebellum to feature an ischaemic encephalopathy (not shown).

The organs of MAb-treated mice that died within $24 \mathrm{~h}$ of challenge presented pathological features similar to those described for the challenged control mice. However, mice that had been treated with the MAb mixture and died within $24 \mathrm{~h}$ showed a lower degree of hydropic degeneration of liver, mainly perilobular, but no signs of necrosis (Fig. 5). In contrast, the organs of the MAb-treated mice that survived the infection and were killed at $24 \mathrm{~h}$ after challenge displayed less severe alterations. The lungs presented focal but inconspicuous thickening of the pulmonary alveolar walls (Fig. 6). The livers displayed minor signs of inflammation, such as mild hepatic reticulo-endothelial cell activation with microvacuolar degeneration (not

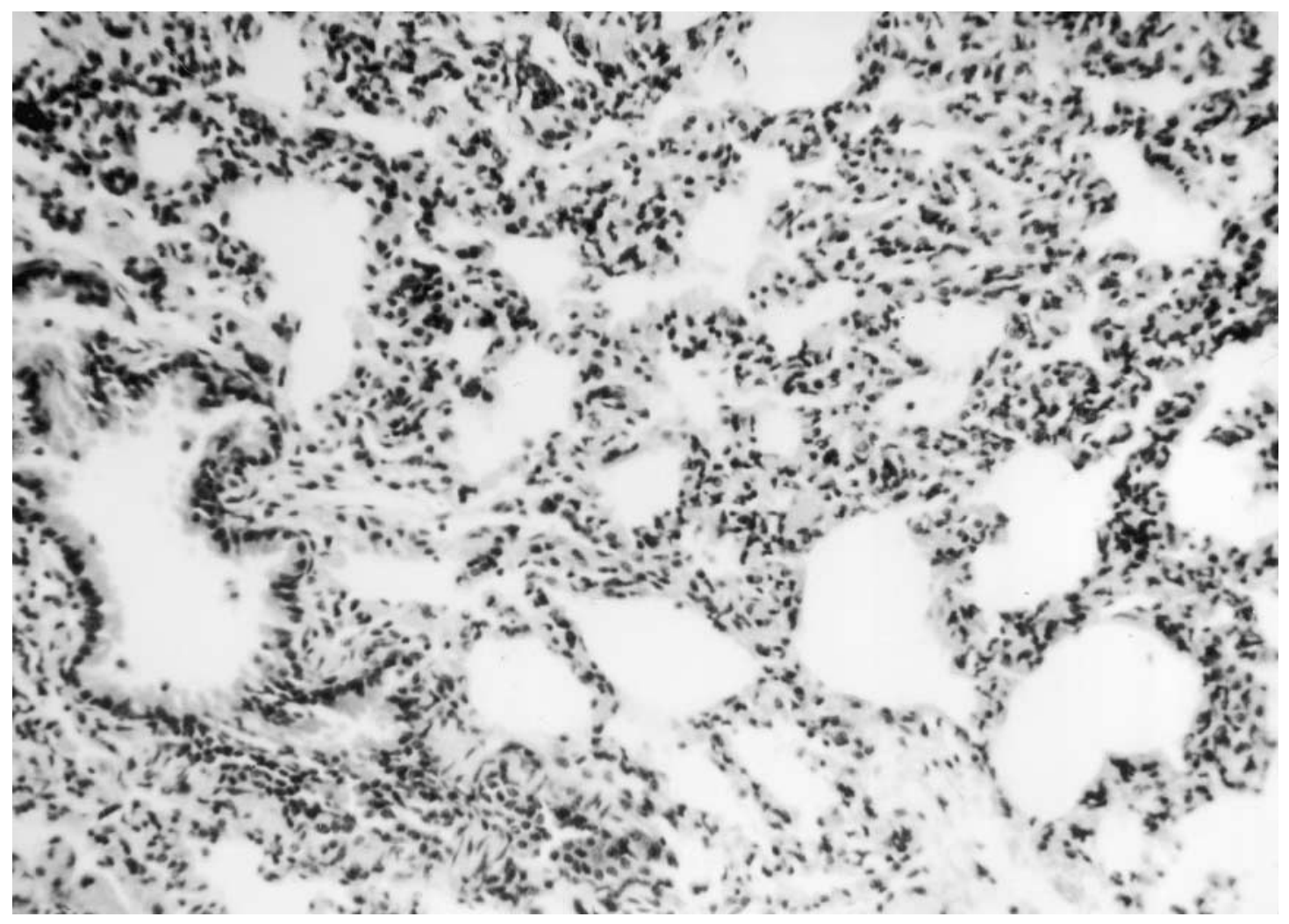

Fig. 3. Section of the lung of a control mouse that died within $24 \mathrm{~h}$ of challenge with $\mathrm{E}$. coli $06: \mathrm{K}^{-}$. The alveolar damage is evidenced by marked thickening of the alveolar septa and obliteration of the lumina $(H \& E \times 100)$. 


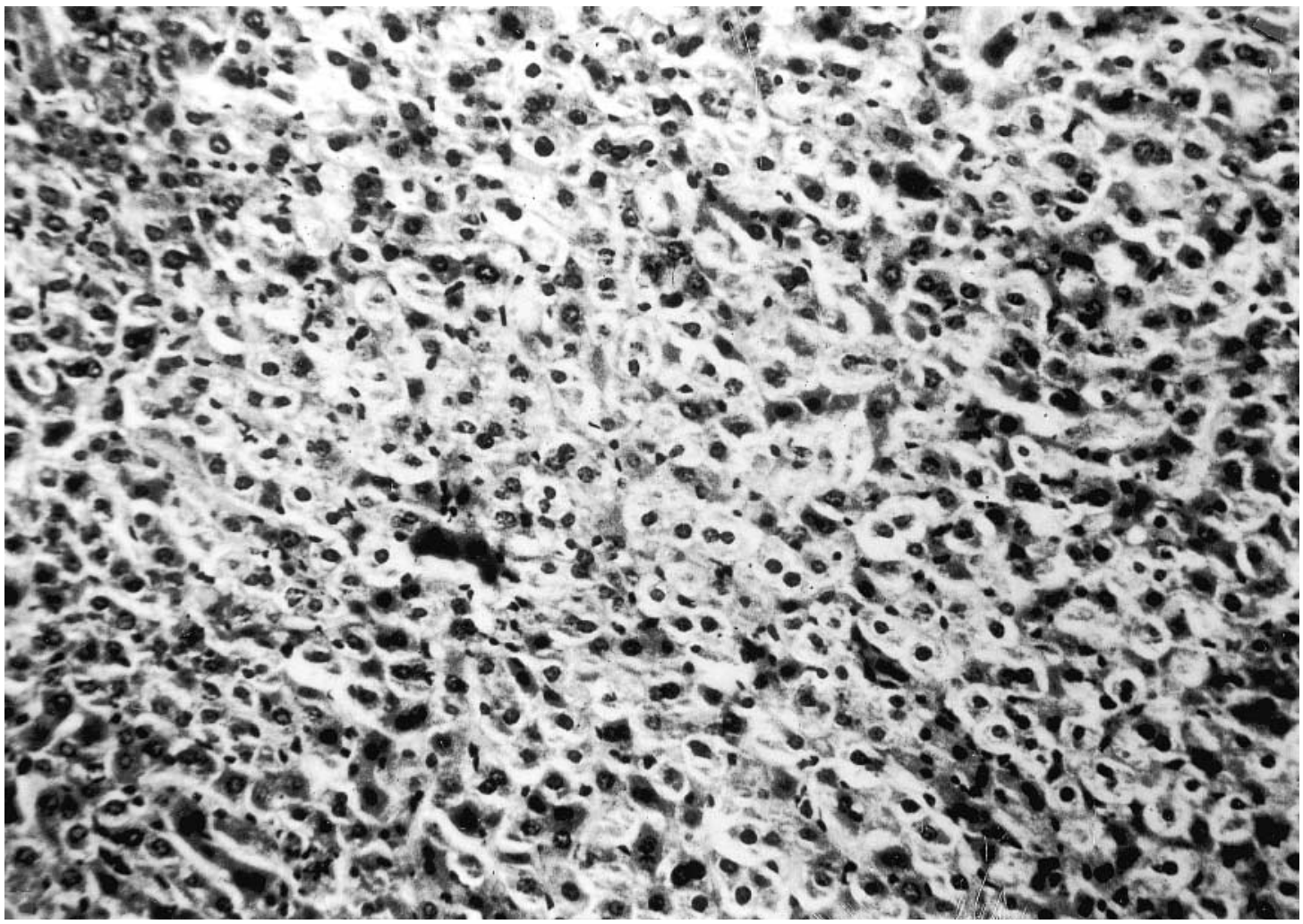

Fig. 4. Section of the liver of a control mouse that died within $24 \mathrm{~h}$ of challenge with $\mathrm{E}$. coli $06: \mathrm{K}^{-}$. The organ shows confluent necrosis. $(H \& E \times 100)$.

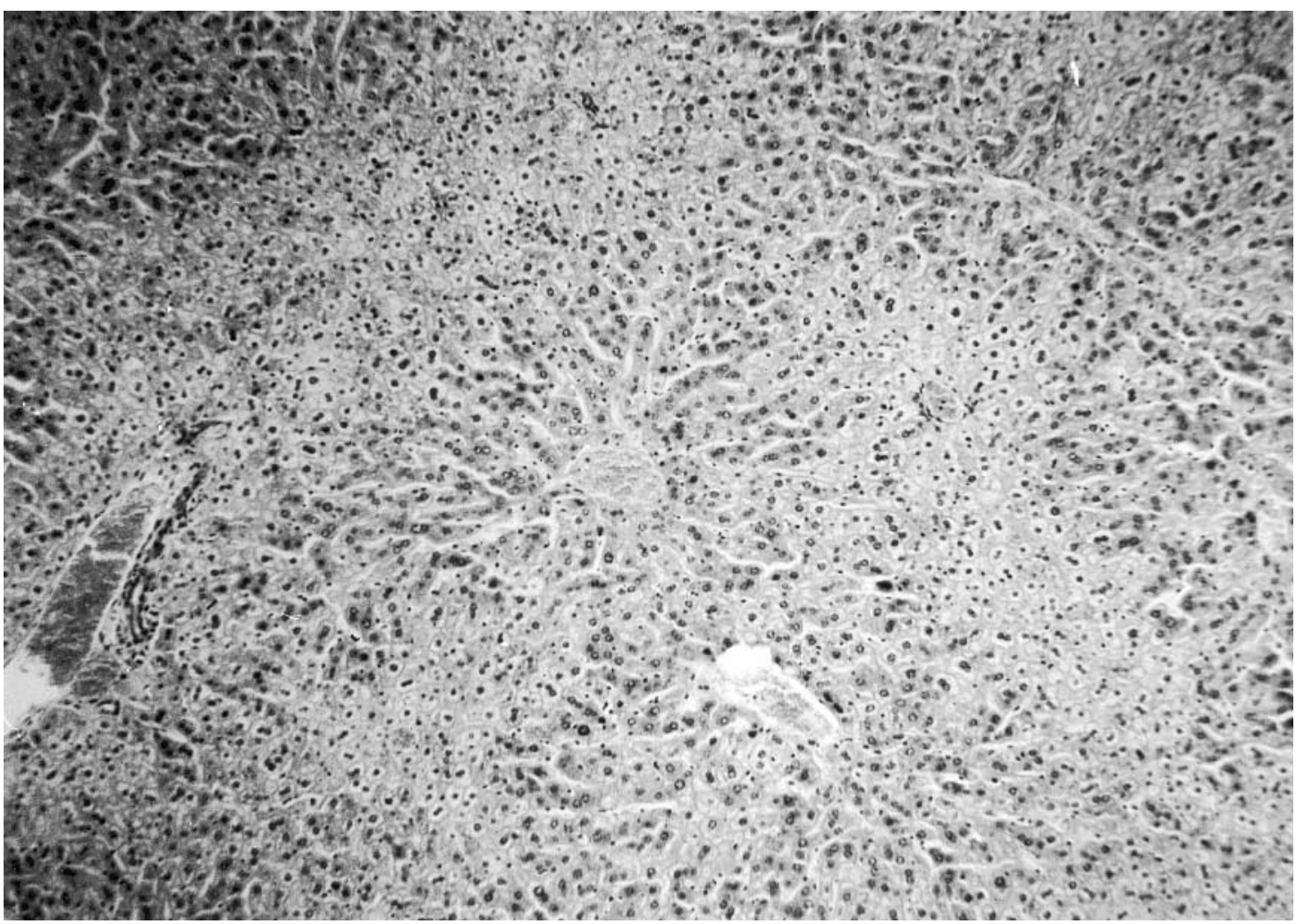

Fig. 5. Section of the liver of a mouse which was pre-treated with the MAb mixture and died within $24 \mathrm{~h}$ of challenge with $\mathrm{E}$. coli $06: \mathrm{K}^{-}$. There are no signs of confluent hepatocellular necrosis, but hydropic degeneration is present $(H \& E$ $\times 100)$. 


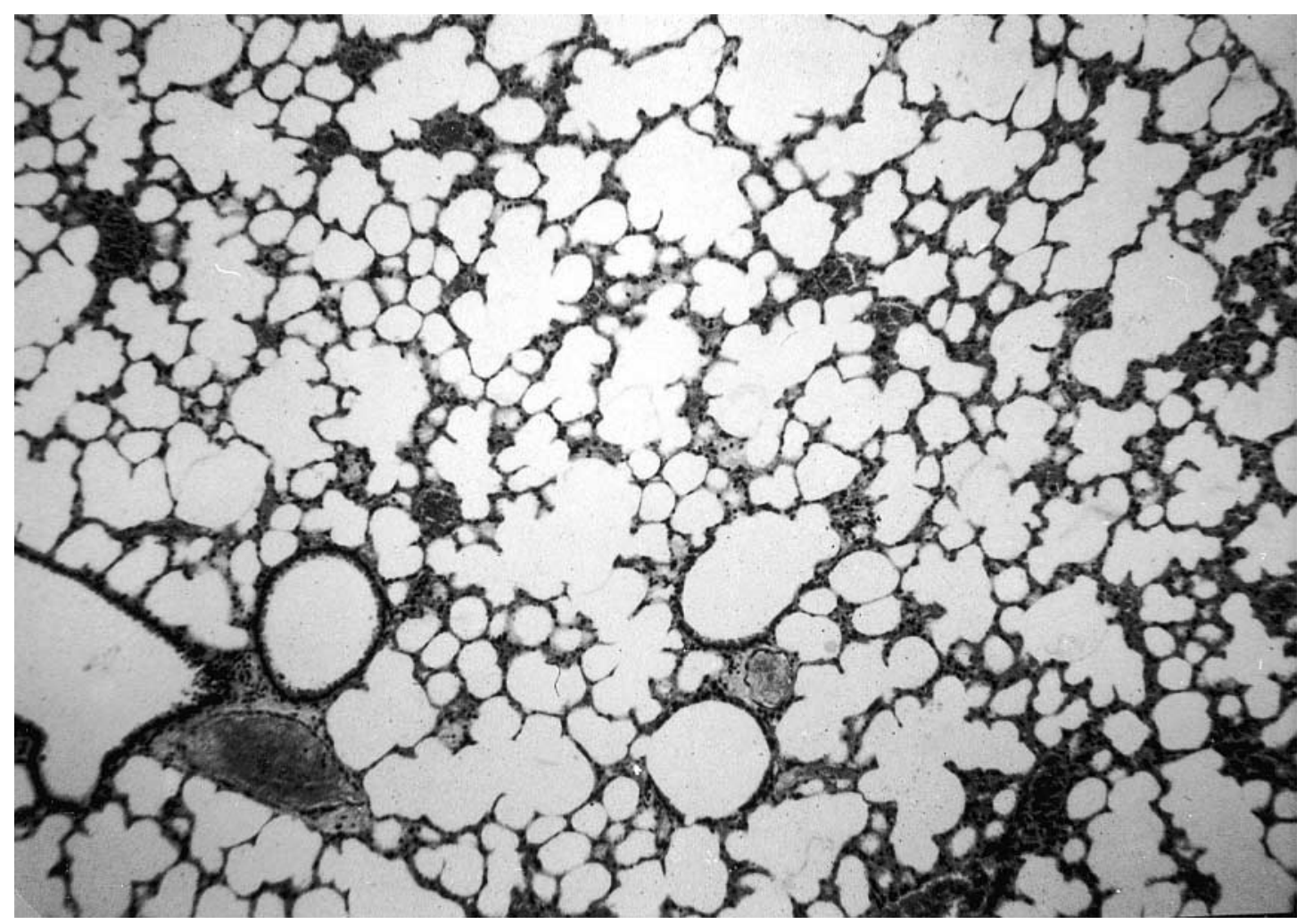

Fig. 6. Section of the lung from a mouse pre-treated with MAb ARM 1-4 and killed $24 \mathrm{~h}$ after challenge with E. coli $06: \mathrm{K}^{-}$. The alveoli appear nearly normal $(\mathrm{H} \& \mathrm{E} \times 100)$.

shown). In surviving mice, pre-treated with the MAbs either singly or in combination, the organs showed a complete restitutio ad integrum after 10 days (not shown).

\section{Discussion}

The results of the present study confirmed that MAbs MTIF and ARM 1-4, elicited in mice after immunisation with antibiotic-treated $\mathrm{E}$. coli $06: \mathrm{K}^{-}$, offered full protection against lethal challenge with $\mathrm{E}$. coli $06: \mathrm{K}^{-}$ and a certain degree of cross-protection against lethal challenge with different $E$. coli serotypes $[19,20]$. When the MAbs were administered together, the crossprotective capacity was significantly improved. MAbs MTIF and ARM 1-4 recognised protein epitopes on the surface of untreated E.coli $06: \mathrm{K}^{-}[19,20]$. Previous reports showed that antibodies to outer-membrane proteins (OMPs) were protective in experimentally induced infection in mice [16-21]. Other authors found anti-OMP antibodies that cross-reacted with protein epitopes of different gram-negative serotypes $[7,24,25]$. Furthermore, Hofstra et al. showed crossreactivity among OMPs of members of the Enterobacteriaceae in crossed immuno-electrophoretic studies [26], and recent studies [14] showed that an antiserum raised to $E$. coli J5 contained high titres of IgG antibodies that bound to at least three major OM Ps on many clinically relevant gram-negative bacteria. Therefore, it is possible that the simultaneous recognition of different protein epitopes on the bacterial surface could account for the enhanced cross-protection observed in mice pre-inoculated with the MAb mixture.

MAbs MTIF and ARM 1-4, given i.p. alone or in combination, controlled the bacterial spread to organs after i.p. challenge. This finding was confirmed by the histological examination of the mice from different experimental groups, which showed that the organs (brain, liver, spleen, lung and kidney) from the surviving MAb-treated mice showed only moderate damage. In contrast, organs from control mice showed diffuse alterations similar to those encountered in the early stages of septic shock [27]. Therefore, it seems that pre-administration of MA bs prevented the cascade of events leading to septic shock which is strongly related to the systemic release of pro-inflammatory cytokines such as TNF- $\alpha$ [27]. Indeed, in the sera of mice pre-treated with MAbs, TNF- $\alpha$ levels were lower than those in untreated mice at $90 \mathrm{~min}$ after bacterial challenge. Furthermore, serum levels of TNF- $\alpha$ correlated with the survival rates of the animals, as high values of the cytokine were associated with high mortality rate. It is widely accepted that endotoxin is the major stimulator of the release of TNF- $\alpha$ by monocytes and macrophages and that endotoxin is continuously released into the bloodstream during a systemic gram-negative bacterial infection [28]. Consequently, it could be hypothesised that pre-administration of MAbs controlled the systemic release of endotoxin. However, the MAbs used in this study were devoid of a direct anti-endotoxin activity. In fact, they recognised bacterial proteins $[19,20]$ and displayed a 
high protective capacity despite the elevation of systemic endotoxin levels after bacterial challenge. The latter effect was probably due to the capacity of the MAbs to activate complement $[19,20]$, thus causing enhanced bacterial death and subsequent raising of systemic endotoxin levels. Therefore, it seems that high levels of circulating endotoxin are not necessarily correlated with a high mortality rate nor with an overproduction of TNF- $\alpha$, especially in the presence of antibodies which may significantly contribute to clearance of the bacteria from the body.

In conclusion, the findings of the present study confirm that M A bs M TIF and ARM 1-4 directed against protein epitopes of $E$. coli provided protection against systemic infection by homologous and heterologous $E$. coli. The heterologous protection was improved by the use of a mixture of the MAbs. The mechanism of protection implied an enhanced bacterial clearance promoted by the MAbs, which were able to prevent both the systemic release of pro-inflammatory TNF- $\alpha$ and the histological lesions normally encountered during a systemic life-threatening gram-negative bacterial infection. These events occurred in the presence of high levels of circulating endotoxin, which highlights the importance of the bacterial cell as a whole in the pathogenesis of gram-negative bacterial infections.

We thank Mr Rocco Fraioli for his skilful technical support in characterising the MAbs. This study was supported in part by a grant from the 'National Research Council' (CNR) target project 'Prevention and Control Disease Factors', subproject 'Causes of Infectious Disease'.

\section{References}

1. Centres for Disease Control and Prevention. Increase in National Hospital Discharge Survey rates for septicemia. United States 1979-1987. MMWR Morbid Mortal Wkly Rep 1990; 39: 31-34.

2. Young LS, Proctor RA, Beutler B, MCCabe WR, Sheagren JN. University of California Davis Interdepartmental Conference on Gram-negative septicemia. Rev Infect Dis 1991; 13: 666-687.

3. Courvalin P. The Garrod Lecture. Evasion of antibiotic action by bacteria. J Antimicrob Chemother 1996; 37: 855-869.

4. Bayston KF, Cohen J. Bacterial endotoxin and current concepts in the diagnosis and treatment of endotoxaemia. J Med Microbiol 1990; 31: 73-83.

5. Fisher CJ, Opal SM, Dahinaut JF et al. Influence of an antitumor necrosis factor monoclonal antibody on cytokine levels in patients with sepsis. The CB006 Sepsis Syndrome Study Group. Crit Care Med 1993; 21: 318-327.

6. Teng NNH, Kaplan HS, Herbert JM et al. Protection against gram-negative bacteremia and endotoxemia with human monoclonal IgM antibodies. Proc Natl Acad Sci USA 1985; 82: $1790-1794$

7. Debroy C, Yealy J, Wilson RA, Bhan MK, Kumar R. Antibodies raised against the Outer Membrane Protein interrupt adherence of enteroaggregative Escherichia coli. Infect Immun 1995; 63: 2873-2879.

8. Salles $M-F, M$ andine $E$, Zalisz $R$, Guenounou $M$, Smets P. Protective effects of murine monoclonal antibodies in experimental septicemia: E. coli antibodies protect against different serotypes of E. coli. J Infect Dis 1989; 159: 641-647.

9. Baumgartner J-D, Glauser MP, MCCutchan JA et al. Prevention of gram-negative shock and death in surgical patients by antibody to endotoxin core glycolipid. Lancet 1985; 2: 59-63.
10. Baumgartner JD, Heumann D, Gerain J, Weinbreck P, Grau GE, Glauser MP. Association between protective efficacy of anti-lipopolysaccharide (LPS) antibodies and suppression of LPS-induced tumor necrosis factor alpha and interleukin 6 . Comparison of 0 side chain-specific antibodies with core antibodies. J Exp Med 1990; 171: 889-896.

11. Baumgartner J-D, Heumann D, Glauser M-P. The HA-IA monoclonal antibody for gram-negative sepsis. N Engl J Med 1991; 325: 281-282.

12. Bhattacharjee AK, Opal SM, Taylor R et al. A noncovalent complex vaccine prepared with detoxified Escherichia coli J5 (Rc Chemotype) lipopolysaccharide and Neisseria meningitidis group B Outer Membrane Protein produces protective antibodies against gram-negative bacteremia. J Infect Dis 1996; 173:1157-1163.

13. Ziegler EJ, Fischer $C J$, Sprung $C L$ et al. Treatment of gramnegative bacteremia and septic shock with HA-1A human monoclonal antibody against endotoxin. A randomized, doubleblind, placebo-controlled trial. The HA-1A sepsis study group. $\mathrm{N}$ Engl J Med 1991; 324: 429-436.

14. Hellman J, Zanzot EM, Loiselle PM et al. Antiserum against Escherichia coli 5 contains antibodies reactive with outer membrane proteins of heterologous gram-negative bacteria. J Infect Dis 1997; 176: 1260-1268.

15. Silva AT, A ppelmelk BJ, Cohen J. Purified monoclonal antibody to endotoxin core fails to protect mice from experimental gramnegative sepsis. J Infect Dis 1993; 168: 256- 257.

16. Bowden RA, Cloeckaert A, Zygmunt MS, Dubray G. Outermembrane protein- and rough lipopolysaccharide-specific monoclonal antibodies protect mice against Brucella ovis. J Med Microbiol 1995; 43: 344-347.

17. De Sa C, Souriau A, Bernard F, Salinas J, Rodolakis A. An oligomer of the major outer membrane protein of Chlamydia psittaci is recognized by monoclonal antibodies which protect mice from abortion. Infect Immun 1995; 63: 4912-4916.

18. Helminen ME, Maciver I, Latimer JL, Cope LD, M cCracken $\mathrm{GH}, \mathrm{H}$ ansen EJ. A major outer membrane protein of M oraxella catarrhalis a target for antibodies that enhance pulmonary clearance of the pathogen in an animal model. Infect Immun 1993; 61: 2003-2010.

19. Lun MT, Amatucci AM, Raponi $G$ et al. Murine monoclonal antibody elicited with antibiotic-exposed Escherichia coli exerts protective capacity in experimental bacterial infections. I Med Microbiol 1994; 41: 179- 183.

20. Lun MT, Raponi G, Amatucci AM, Natali PG, Fraioli R, Mancini C. Characterisation and protective capacity of monoclonal antibodies elicited in mice against protein epitopes of antibiotic-exposed Escherichia coli. J Med Microbiol 1997; 46: $122-128$.

21. von Specht B-U, Knapp B, Muth $G$ et al. Protection of immunocompromised mice against lethal infection with Pseudomonas aeruginosa by active or passive immunization with recombinant $\mathrm{P}$. aeruginosa outer membrane protein $\mathrm{F}$ and outer membrane protein I fusion proteins. Infect Immun 1995; 63: $1855-1862$.

22. Raponi G, Lun MT, Lorino $G$ et al. Reactivity and protective capacity of a polyclonal antiserum derived from mice immunized with antibiotic exposed Escherichia coli. J Antimicrob Chemother 1993; 31: 117-128.

23. Ruff MR, Gifford GE. Purification and physico-chemical characterization of rabbit tumor necrosis factor. I Immunol 1980; 125: 1671- 1677.

24. Goldblatt D, Scadding GK, L und VJ, Wade AM, Turner MW, Pandey JP. Association of $\mathrm{Gm}$ allotypes with the antibody response to outer membrane proteins of a common upper respiratory tract organism, Moraxella catarrhalis. J Immunol 1994; 153: 5316-5320.

25. Kervella $M$, Fauchère $J-L$, Fourel $D$, Pagès J-M. Immunological cross-reactivity between outer membrane pore proteins of Campylobacter jejuni and Escherichia coli. FEMS Microbiol Lett 1992; 99: 281-286.

26. Hofstra H, van Tol MJD, Dankert J. Cross-reactivity of major outer membrane proteins of Enterobacteriaceae, studied by crossed immunoel ectrophoresis. J Bacteriol 1980; 143: 328- 337.

27. Tracey K, Beutler BR, Lowry SF et al. Shock and tissue injury induced by recombinant human cachectin. Science 1986; 234: 470- 474

28. Rietschel ET, Brade H. Bacterial endotoxins. Sci Am 1992; 267: $54-61$. 